\title{
Reglering som policyfråga: \\ En diskussion om regleringens effekter vid ekonomisk brottslighet
}

\author{
Av Tage Alalehto ${ }^{1}$
}

\begin{abstract}
This essay discusses the regulation of white-collar crime. It reviews the development of white-collar crime regulation from various angles considering: 1) the extent and structure of white-collar crime, and 2) the ways in which these characteristics affect the ability of regulation to restrain white-collar offending on institutional, organisational and individual levels. The conclusion is that regulation must be multifaceted if it is going to be able to address white-collar crime's many forms. Patterns of white-collar crime are just as heterogeneous as those of street crime. While tax crime is very frequent and demands a specific regulatory response, bribery is less frequent and requires a completely different response. Like street crime, white-collar crime is committed by both occasional and "chronic" offenders. Effective regulation must be able to deal with crimes committed by both types of offenders.
\end{abstract}

\section{Inledning}

Reglering är ett sammansatt komplex av åtgärder på olika nivåer inom jurisdiktionen, som syftar till att stävja upp olämpligt beteende. Inom agendan för den ekonomiska brottsligheten har en hel del forskning inriktat sig på att studera regleringsåtgärder som omfattat alltifrån reglering av brottsligt beteende genom straffrätten, till misskött beteende via civilrätten till olämpligt beteende via den påtagligt »mjukare« förvaltningsrätten.

Men reglering omfattar idag mer än så, under de gångna årtiondena har vi dels sett en utbyggd självreglering genom branschorgan ( $\mathrm{t}$ ex börsinspektionen), dels en myndighetstillväxt som syftat till att övervaka och reglera konsumentrelaterade verksamheter som en följd av masskonsumtionssamhällets framväxt ( $t$ ex Livsmedelsverket, Konsumentverket, etc). När det gäller självregleringen har det

* Title in English: Regulation as policy issue: a discussion of the efficiency of regulation of white collar crime. 
skett till följd av att den kapitalistiska marknaden utvidgats så att ännu fler internationella aktörer kommit in i bilden, vilket ökat konkurrenstrycket totalt i marknaden. I syfte att upprätthålla en reglerad konkurrens har övervakningen överlag intensifierats för att skapa jämbördiga konkurrensvillkor som gynnar marknaden/branschen/företaget i sin helhet genom att prioritera de mest kompetenta och seriöst satsande aktörer inom respektive näringsnisch att gå in och investera sitt kapital. Det har krävt att alla aktörer, oavsett fysisk placering, skall ha samma tillgång till information om marknaden, branschen eller företaget vid samma tidpunkt. Ingen skall missgynnas genom t ex insiderhandel, kartellbildning, bokföringsmanipulation, etc att riskera sin investering vilket i sin tur riskerar att missgynna marknadens balans i sin helhet av en sund och kompetentbaserad konkurrens (för en översikt se Larsson, 2011).

När det gäller myndighetsregleringen av konsumentprodukter har det rört sig om en global strukturell transformering av det ekonomiska systemet, hårt driven av en kapitalistisk tillväxtfilosofi, som gått från produktion till konsumtion som den främsta motorn för ekonomisk tillväxt. Samt en allt högre teknisk komplexitet, med ökat inslag av kemikalier eller andra fysiska egenskaper som riskerar att utsätta konsumenten för ökad risk vid hanteringen av produkten gällande dennes hälsa och säkerhet (Croall, 2009). Här har regleringen främst skett via statlig kontroll och statlig intervenering, både nationellt och internationellt via ratificerade avtal. Men också via olika typer av självreglering från marknaden via olika typer av certifierande myndigheter eller organisationer, som godkänt produkten i ett visst avseende. Samt reglering via så kallad tredjepart där konsumenten skolats att ställa krav på produkten ifråga när det gäller pris, kvalité och miljökonsekvenser (Gibbs mfl., 2010). Ett typiskt exempel på tredjepartsreglering för svensk del är tv-programmet »Plus«, där företaget ställs till ansvar för produkten eller tvprogrammet »Lyxfällan«, där konsumenten ställs till ansvar för sitt oansvariga konsumtionsbeteende.

Syftet för denna artikel är att diskutera vad regleringsforskning om ekonomisk brottslighet bör ta hänsyn till när det gäller 1) den ekonomiska brottslighetens utbredning och struktur, och på vilket sätt detta påverkar 2) regleringars verkan och effekt att stävja den ekonomiska brottsligheten. Den andra punkten gäller inte minst de resultat man funnit vid forskning om ekonomisk brottslighet på de tre abstraktionsnivåerna samhälle, organisation och individ. Det vill säga, reglering av ekonomisk brottslighet som ett utbrett och aggregerat fenomen på samhällsnivå, partikulär reglering av ekonomisk brottslighet på organisationsnivå och marginaliserad reglering av ekonomisk brottslighet på individnivå. 


\section{Tidigare forskning}

Frågan om man skall reglera via lagstiftning eller via samförståndsskapande åtgärder är en »gammal« frågeställning i det brottsförebyggande arbetet mot ekonomisk brottslighet (Gray, 2006). Den vanligaste modellen när det gäller reglering av ekonomisk brottslighet är av strikt ekonomisk, legalistisk och individuellt orienterad art. Man utgår från att individens laglydnad är en effekt av upptäcktsrisk och sanktionsform. Modellen bygger på ett mer eller mindre påtvingat legalistiskt samtycke, dvs företagaren följer lagen men delar inte alltid dess värdegrund (Braithwaite och Makkai, 1991). Det innebär att vid de tillfällen när upptäcktsrisken är liten och sanktionsformen är mild så överväger företagaren brott utifrån sin värdepreferens. Detta är ett relativt vanligt argument när det gäller just ekonomisk brottslighet. En mer sociologiskt orienterad modell menar istället att laglydnad inte enbart kan regleras genom individens instrumentella och legalistiska syn på upptäcktsrisk och sanktionsform vid en given situation, utan i lika hög grad även av dennes kollegiala bindningar och sociala investeringar i nätverk och signifikanta grupper som berör denne som person (Hetzler, 2003). Det vill säga normativa bindningar att uppträda konformt och normalt. Denna sociologiska orientering har ändat i en regleringsform som betonar integreringen mellan »mjuka« och »hårda« regleringar. Ett känt exempel på detta är »responsiv reglering« av Ayres och Braithwaite (1992) i form av en regleringspyramid. Vid första överträdelsen ges en informell varning från myndighetssynpunkt; vid andra överträdelsen ges en formell varning och vite; vid tredje följer anmälan, förundersökning och åtal; vid fjärde överträdelsen följer böter och straff enligt straffrätten. Det modellen syftar till är en moralisk reaktion på överträdelsen, som vädjar till överträdarens samvete att skärpa sig. Om inte detta räcker stegras sanktionsformens hårdhet.

Tankegången att företagarens beteende kan regleras genom »mjuka« regleringsformer som vädjar till förövarens samvete eller till dennes egenskaper att fortsättningsvis framstå som en god medlem i sitt sociala nätverk anses speciellt relevant när det gäller just ekonomiska brottslingar. Man kan på goda grunder anta att en ekonomisk brottsling har fler positiva värden att förlora än en traditionell brottsling ifall denne upptäcks och fälls. Det gäller alltifrån förlusten av sitt goda rykte, sin höga lön, status och förtroende till stigmatisering av denne som affärsman (Braithwaite, 1985; Wheeler; Mann och Sarat, 1988; Benson och Cullen, 1998).

Utifrån denna utgångspunkt är det följdriktigt att anta att den laglige företagaren avskräcks från att begå brott eftersom straffet och den personliga förlusten blir för stor. Denna utgångspunkt har varit föremål för en rad studier på området 
(Braithwaite och Makkai, 1991; Simpson, 1992; Coffe, 1995; Paternoster och Simpson, 1996). Resultaten pekar dock i olika och statistiskt sett ganska svaga riktningar (Simpson och Koper, 1992). Vid studier av direkta avskräckningseffekter, genom civilt eller rättsligt myndighetsutövande mot direkt utpekade företag har man observerat signifikanta effekter (Paternoster och Simpson, 1996:579). Detsamma gäller vid en form av indirekt avskräckning i lokala distrikt med aktiva åklagare, kända för att driva ekobrottsmål, vilket gjort företagarna mer sensitiva för negativ publicitet i syfte att undvika åtal (Benson och Cullen, 1998:100-102). Men vid studiet av indirekta effekter (dvs som ett allmänt hot) har man inte observerat någon signifikant avskräckningseffekt (Braithwaite och Makkai, 1991:35).

En närstående frågeställning till studiet av förebyggande avskräckningseffekter är studiet av sanktioner och dess eventuella avskräckningseffekter mot omgivningen vid de tillfällen när åtal väckts och dom fallit. Det gäller studier av böter (Posner, 1995) eller fängelse och böter (Coffe, 1995; Mann, Wheeler och Sarat, 1995) eller fängelse (Weisburd mfl., 1995) eller utformningen och framställningen av lagrum som avskräckningsinstrument (Levi och Dorn, 2006). Resultaten varierar beroende på vilken nivå man mäter och vilka sociala kategorier man vill avstyra från brottsligt beteende, $t$ ex ger inte fängelsevistelse några egentliga avskräckningseffekter på karriärkriminella ekobrottslingar medan hot om fängelse kan avskräcka tillfälleskriminella ekobrottslingar (Smith mfl., 2007). Studiet av andra påföljder än fängelse och böter är t ex att döma företaget till sociala kostnader (externalities) som drabbar dess anseende och status (Walt och Laufer, 1992), eller informella reaktioner som drabbar företagen t ex en köpbojkott eller en konsumentdemonstration (Grabosky och Shover, 2010). Det finns dock inga kända empiriska studier som undersökt dessa senare ansatser. En annan sanktionsform som diskuterats på senare tid är tillämpningen av negativ publicitet. Inom denna forskningsagenda har främst Fisse och Braithwaite (1983) och Kahan och Posner (1999) diskuterat påverkan av negativ publicitet av företag som misstänkts för oredliga handlingar. Framför allt har Kahan och Posner föreslagit offentlig skamgörelse som kompletterande påföljd till böter, villkorlig dom och fängelse, för ett företag eller en direktionsmedlem som begått ett ekonomiskt brott. Effekterna av negativ publicitet har dock visat sig vara kortvarigt instrumentella i motsats till långsiktigt moraliska, där marknadens aktörer reagerat på publiciteten genom att sälja ut sina andelar av företaget i syfte att hämta hem den vinst som varit möjlig att hämta hem. Och efter en tid när publiciteten lagt sig, börjat köpa igen av företagets aktieandelar (Levi, 2002; Alalehto, 2007). 


\section{Vad är det då som skall regleras?}

Ja egentligen allt som är fel, och i huvudsak ett fel begånget av en verksam näringsidkare! Men alla fel som begås är inte per definition brottsliga så vad menas då med det felaktiga och hur stort är det? Det är här saker och ting blir lite komplicerat, för det beror på vad vi räknar som brottsligt felaktigt och vilken volym det kommer att ta sig för det som skall regleras. Om vi utgår från Sverige, så bestod det totala antalet näringsidkare 2010 av 977556 registrerade företag (aktiebolag, kommanditbolag, handelsbolag, bankaktiebolag, enskild näringsidkare, ekonomisk förening, medlemsbank, sambruksförening, sparbankförsäkringsaktiebolag, ömsesidigt försäkringsbolag och bostadsförening). ${ }^{2}$ Om vi jämför detta tal med antalet anmälningar av olika slag som reglerande myndighet fătt in, så ligger talet på drygt 166000 för 2010. ${ }^{3}$ Med detta tal som bas är det svårt att uttala sig om det eventuella mörkertalet, men vi kan nog vara rätt övertygade om att det faktiska talet är större än inkommande anmälningar eftersom det säkerligen finns en del missnöjda kunder som inte gjort någon anmälan. ${ }^{4}$ Hur som helst, med denna »beslutsansats« utgår man från att räkna in hela raddan av anmälningar som kan gälla allt från en kunds missnöje med en köpt produkt till en brottslig handling mot staten. Det vill säga i princip det som Edwin Sutherland (1985) anförde när han inkorporerade criminology med criminal justice. Det gäller anmälningar som för svensk del avser ärenden som behandlas av Allmänna reklamationsnämnden, Konsumentverket, Miljöverket, Livsmedelsverket, Marknadsdomstolen, Arbetsmiljödomstolen, etc. Med utgångspunkt i de negativa myndighetsbesluten talar vi om ekonomisk brottslighet som ett fenomen av sociologiskt snitt, eftersom relationen mellan antalet negativa myndighetsbeslut och antalet näringsidkare utgör drygt 17 procents beslutsfrekvens. Det vill säga, drygt var sjätte näringsidkare erhöll rakt av ett negativt myndighetsbeslut år 2010. Detta är ett (bland flera) sätt att mäta en relation som påverkar vår syn över hur reglerandet ser ut, men mer om detta nedan.

Man kan vända på detta och fråga sig om vi verkligen skall anta Sutherlands breda definitionsansats. Ligger det inte närmare sanningen att mäta av en relation mellan antalet näringsidkare och antalet faktiska polisanmälningar under ett år, som utgör ett storleksmått på ungefär hur allvarlig allmänheten uppfattar att den ekonomiska brottsligheten är. Och utifrån denna utgångspunkt diskutera reglerandets betydelse av ekonomisk brottslighet? Oavsett vad vår inställning är $\mathrm{i}$ denna fråga så kan jag konstatera att om man jämför antalet näringsidkare med antalet brottsanmälningar över ekobrott 2010, 38245 stycken, ${ }^{5}$ då finner vi en storleksordning av drygt 4 procent rakt av. Då bör vi komma ihåg att flertalet av dessa anmälningar inte gäller brott begångna för företagets räkning, så kallad corpo- 
rate crime, utan av brott mot företaget i fråga eller via företaget ifråga mot andra företag/organisationer/personer, så kallad white collar crime. Även om vi här räknar med ett mörkertal, låt säga det dubbla mot anmälningstalet för svensk del, så är det inte frågan om ett massfenomen i sociologisk mening. I själva verket står den anmälda brottsligheten för en marginell andel företag (eller personer inom företagen) som utför ekonomiska brott, vilket definitivt kommer att påverka vår syn på reglerandets relevans av ekonomisk brottslighet för samhällets räkning. Det är t ex inte ett massfenomen i liknande betydelse som den som blev följden när Sovjetunionen kollapsade 1991, när marknaden transformerades från en Statsstyrd planekonomi till en nyliberal marknadsekonomi med en passiv och beskuren statsapparat. ${ }^{6} \mathrm{I}$ ett försök att få igång marknaden erbjöd den nyblivna Ryska staten de ryska medborgarna vouchers som gav dem en viss ägarandel av statens egendom att göra i princip vad de ville med. Men eftersom få ryssar hade någon erfarenhet av privat ägande eller av marknadsekonomisk konkurrens, så visste de allra flesta inte vad de skulle göra med sina vouchers. Kriminellt erfarna individer fick då ett utrymme att utan någon egentlig kontroll och reglering möjlighet att köpa dessa vouchers till rena realisationspriser. Detta skedde samtidigt som den ryska staten och dess reglerande myndigheter befann sig i ett »blöjstadium« (Fituni, 2000:24). Ryska forskare har visat att av dem som köpte dessa vouchers i stora kvantiteter hade 40 procent tidigare erfarenhet av svart börshandel, 22.5 procent hade minst en brottsmisstanke och 25 procent hade haft kontakt med Rysk organiserad brottslighet. Den Ryska staten gjorde till en början ingen större notis kring detta. Det gällde att snabbt få igång en fungerande marknadsekonomi som visade sig utbrett en betydande ekonomisk brottslighet i landet. ${ }^{7}$ När väl den Ryska staten uppmärksammade problemet ökade antalet anmälda mutor från 1992 till 2003 med över det dubbla (Gilinskiy, 2006) och antalet förundersökningar gällande ekonomiska brott ökade trefalt på bara tre år (37065 fall 1993 till 114970 fall 1996) (Fituni, 2000).

En liknande utveckling har även observerats i Kina i samband med den nya ekonomiska politiken från 1979 som syftat till att successivt frigöra marknaden från statlig detaljkontroll till friare marknadskrafter. Det är en utveckling som fört Kina från en statligt styrd planekonomi till en hybrid av socialistiskt styrd politik med en marknadsorienterad ekonomi, i syfte att attrahera de inhemska bönderna till ökad marknadshandel och locka utländska kapitalinvesterare till Kina (Brody och Luo, 2009). En utveckling som på flera sätt bidragit till Kinas ekonomiska framgång, men dessvärre samtidigt bidragit till en eskalerande moralisk kollaps för landet. Traditionella konfucianska värderingar som la tonvikt på kollektivism och starka sociala band till familj och nära bekanta, har ersatts av ett egenintresse 
att se till sina egna behov och en utpräglad individualism som norm. Samtidigt som staten försvagats och en vacklande politik blivit följden bestående av iscensatta reformer som i princip lika kvickt dragits tillbaka när de väl sjösatts. Sammantaget har denna utveckling lett till en attityd hos den kinesiska allmänheten av ta-det-du-kan-så-fort-du-kan i syfte att säkra sina tillgångar (Deng och Cordilia, 1999). Alltsedan 1989 har den ekonomiska brottsligheten i Kina ökat stadigt åtminstone en bit in på 2000-talet (Brody och Luo, 2009).

\section{Reglerandets komplexitet}

Att mäta den ekonomiska brottsligheten via brottsanmälningar, brottsmisstänkta eller via lagföringar är ett sätt att ange storleksgraden för vad som skall regleras. Låt vara att det är ett ganska snävt sätt, eftersom den är avhängig vetskapen om brott hos offer och dennes anmälningsbenägenhet överlag, liksom av den selektionsprocess som råder inom rättskedjan (Korsell, 2003; se även Levi \& Dorn, 2006 som hänvisar till just Korsell). Och dessutom den selektion kring anmälningsförfarandet som reglerande myndigheter förhåller sig till beroende på deras överordnade regleringsstrategi att endera straffa, vägleda eller övertala (Larsson, 2002). Att mäta den ekonomiska brottsligheten genom antalet negativa myndighetsbeslut ger som vi ser en helt annan bild av den ekonomiska brottslighetens storlek där myndigheterna försöker reglera via vite och bot enskilda företags uppträde, då kan volymerna stiga ända upp till 85-90 procent av företag inom branscher eller sektorer som någon gång under en avgränsad tidsperiod fătt någon typ av regleringsbeslut mot sig. I så måtto kan vi tala om ett massfenomen i sociologisk mening, där reglerandet har betydelse för samhället. Men fortfarande kvarstår frågan om vi anser, ur regleringssynpunkt, att ekonomisk brottslighet är att likställa med ett brott i mer generella förvaltningsrättsliga termer eller ett brott i straffrättslig mening?

Det finns dock en infallsvinkel som kan möta dessa två ansatser. Självrapporterade studier (endera i form av egenrapporterad brottslighet eller offerrapporterad brottslighet) visar att den ekonomiska brottsligheten i straffrättslig mening är i själva verket, föga förvånande, betydligt större än det officiella anmälningstalet, och egentligen högre än antalet negativa myndighetsbeslut. I den senaste undersökningen av Price Waterhouse Coopers (2011), där man frågat 323 nordiska företagare (Danmark, Finland, Sverige och Norge) om de blivit utsatt för ett ekonomiskt brott under det senaste året, uppgav 61 procent att de blivit förskingrade; 28 procent att de råkat ut för ett bokföringsbrott och 24 procent att de utsatts för ett datorrelaterat bedrägeri. ${ }^{8}$ Det skall förstås påpekas att PwC-rapporten innehar betydande problem i det att dess bastal är litet på grund av ett genomgående lågt 
bruttourval per nation och ett stort externt bortfall som gör att urvalet blir starkt selektivt (se Ellingsens kritik, 2010). Ett betydligt bättre statistiskt underlag ges istället i de Norska kombinerade offer- och egenrapporterade brottsundersökningarna som Ellingssen och Sky (2005) och Ellingsen (2010) redovisar. Deras studier visar att offerskapet är volymmässigt betydligt beskedligare än vad Pwc anger, nämligen på en nivå av drygt 20 procent (Ellingsen och Sky, 2005) och fem år senare på en nivå av drygt 17 procent (Ellingsen, 2010). Utifrån 2005 års undersökning konstaterade Ellingsen och Sky att mellan 8 till 10 procent uppgav offerskap vid sex olika typer av ekonomisk brottslighet, samt att den egenrapporterade brottsligheten låg på en nivå av 3 till 4 procent på de ingående sex brottstyperna. När det gällde skattebrottsligheten angav Ellingsen och Sky (2005) en nivå av drygt 6 procent bland företagare. Det vill säga nivåer som ligger ungefär i paritet med de svenska myndighetsbesluten å ena sidan och brottsanmälningarna till svensk polis å andra sidan.

Frågan är dock om Ellingsen och Skys respektive Ellingsens undersökningar utgör valida mätningar av fenomenet som sådant? Det vet vi egentligen inte, utan deras undersökningar måste liksom alla andra liknande undersökningar ställas i relation till andra självrapporterande undersökningar som t ex den av Williams och Renooys (2008) rörande svartarbetets utbredning totalt (företagare och enskilda). Gör man då detta då blir resultatet delvis annorlunda beroende på att de senare mäter skattebrottslighet begånget av flera olika sociala kategorier, i motsats till att mäta av endast en social kategori. Enligt Williams och Renooy utförde hela 18 procent av den arbetsföra befolkningen i Danmark (högst placerad av samtliga länder) ett svart arbete under den ettåriga mätperioden, mot 10 procent $\mathrm{i}$ Sverige (femte plats). Enligt den svenska ekobrottsmyndigheten (2009) motsvarade detta drygt 800000 individer. Med andra ord ett betydligt högre antal brott än vad som uppges genom brottsanmälningar och andelen negativa myndighetsbeslut, vilket för övrigt indirekt kommenteras av Ellingsen och Sky i det att endast var femte brott som en företagare utsatts för ledde till polisanmälan. ${ }^{9}$ Den bild som Williams och Renooy ger förstärks ytterligare i European Social Survey (2004) där drygt 32 procent av det svenska urvalet uppger att de åtminstone en gång under de senaste fem åren begått ett moms- eller skatterelaterat brott. ${ }^{10} \mathrm{Ef}$ tersom urvalet är framtaget genom OSU (obundet slumpmässigt urval) så representerar urvalet den svenska populationen i stort. Det innebär i grova drag att 32 procent motsvarar drygt 2,5 miljoner svenskar som begått åtminstone ett momsbrott av 7,5 miljoner straffmyndiga personer. Detta är definitivt ett sociologiskt fenomen av rang. I absoluta tal är det framför allt medelklassen som utför momsbrotten och i relativa tal är det framför allt företagarna som är klart dominerande 
och överrepresenterad när det gäller denna brottsstruktur. Men om vi jämför begångna försäkringsbedrägerier och mutor från ovanstående ESS-undersökning, då uppgav drygt 3 procent (försäkringsbedrägeri) respektive 1 procent (muta) att de begått något av brotten de senaste fem åren. ${ }^{11}$ Detta motsvarar drygt 225000 individer som begått försäkringsbedrägerier respektive 75000 som begått mutor (Alalehto och Larsson, 2008). Det är förvisso fortfarande ett sociologiskt intressant fenomen, men knappast ett makrosociologiskt fenomen av rang. En andel av denna storlek kräver att vi nog bör titta mer på de egenskaper som präglar dessa individer, än de strukturella förutsättningar som råder för individerna.

\subsection{Reglerandets nivåindelning}

I viket fall, förutom det betydande mätproblem som ovanstående genomgång vittnar om, ger ovanstående argument prov på att diskussionen om regleringar kanske inte bör riktas ensidigt till att betrakta ekonomisk brottslighet som å ena sidan ett aggregerat fenomen eller som å andra sidan ett marginaliserat fenomen. Det råder helt enkelt skillnader i hur utbredda olika brottstyper är i förhållande till varandra, vilket kräver en mer nivåindelad regleringsstrategi av å ena sidan allmänt riktade regleringar, å andra sidan specifikt riktade regleringar mot vissa marginella yttringar.

Denna bild av nivåindelad regleringsstrategi kan förstås bättre om vi till exempel gör en skillnad på »köpare« och »säljare« av svart arbete på aggregerad nivå. Halleröd och Larsson (2008) visar att det är speciellt småföretagare som uppvisar en signifikant avoghet i fråga om skattemoral, jämfört med andra sociala kategorier. Utifrån incitamentsstrukturer kan vi få ut tre tydliga kategorier av skattebrottslingar: Småföretagare (både i egenskap av köpare och säljare), medelklass (i egenskap av köpare) och ungdomar (i egenskap av säljare) som rekryteringsbas för svart arbete. De materiella villkoren i Halleröds och Larssons undersökning visar att ett av skälen att det är just småföretagare som köper och säljer svart arbete beror på att var fjärde småföretagare definieras som fattig (tjänar $60 \%$ eller mindre i median än den genomsnittliga inkomsten för landet) $\mathrm{i}$ jämförelse med arbetslösa där var femte definieras som fattig. Det sista gäller speciellt ogifta, icke-samboende ungdomar (18-24 år). Genom detta förfarande får vi fram en bild som tydliggör den demografiska variationen och de materiella villkoren av vilka som är »köpare« respektive »säljare« av svart arbete.

Det är en bild som specificeras ytterligare genom en undersökning av Larsson och Halleröd (2011) baserad på SILK-data för 2007, som beskriver att det är framför allt en yngre arbetare och småföretagare som riskerar att vara en s k working poor i betydligt högre utsträckning än en medelålders arbetare. Det här gäller 
arbetare/småföretagare som är lågavlönade (högst $66 \%$ av medianförtjänst) i förhållande till högavlönade. Ett sådant förhållande kan beskriva varför just yngre arbetare/småföretagare är benägna till svartarbete än medelålders utifrån lagen om avtagande marginalnytta (se Halla och Schneider, 2008). Det vill säga, ju mindre formell inkomstnivå en individ har desto större marginalnytta har denne att begå svartarbete (även i liten skala) eftersom det drygar ut inkomsterna väsentligt för denne. Detta i motsats till en individ som redan har en relativt hög inkomstnivå vilken i så fall måste arbeta betydligt mer svart för att få en lika stor marginalnytta som den förre individen, vilket då sänker den senares incitament att arbeta svart överhuvudtaget. Det är också en kalkyl som skall vägas mot de risker för upptäckt och sanktion som kan föreligga för höginkomsttagare gentemot låginkomstintagare.

Ett annat sätt att diskutera nivåindelningen av regleringars betydelse kan utgå från den distinktion som diskuterats livligt inom amerikansk kriminologi, nämligen skillnaden mellan prevalance å ena sidan och incidence å andra sidan. Det är en diskussion som varit ordentligt på tapeten i den amerikanska kriminologin alltsedan »life-course paradigmet« introducerades (se Blumstein, 1986). Frågan gäller hur utbredd en viss typ av brottslighet är i förhållande till hur frekvent brottsligheten fördelar sig inom olika sociala kategorier. För att tala klarspråk: om vi syftar till att reglera den ekonomiska brottsligheten på det sätt som t ex Sutherland föreslår, då talar vi om en utbredd (prevalent) brottslighet som definitivt är ett sociologiskt fenomen. Denna ansats lyfter fram regleringsanspråken till ett policyplan där ekonomisk brottslighet måste motverkas genom allmänna regleringar ( $\mathrm{t}$ ex vid skattebrottslighet). Därför att den förövarkategori vi talar om här gäller främst tillfälleskriminella, som är lättare att avstyra från brott via $\mathrm{t}$ ex hot och stimulera till lagligt beteende genom att få dem att samverka med lagens intentioner om hoten görs uppenbara. Men om regleringen av den ekonomiska brottsligheten istället inriktas mot den andra ansatsen (incidence), att stävja enskilda företag/individer som begår frekvent mycket brottslighet givet en viss tidsrymd ( $\mathrm{t}$ ex de senaste fem åren) i motsats till tillfälleskriminella, då talar vi här om ett marginellt fenomen. Kriminologiskt sett så kommer det här att ge minst två olika regleringsstrategier. Den första ansatsen kräver att man inriktar regleringarna mot medborgarna/företagandet som sådant på samhällsnivå (se t ex Larsson, 2002). Det är samhällsinriktade åtgärder som krävs, kanske till och med internationella överenskommelser. Den andra ansatsen kräver däremot att regleringarna inriktar sig mot organisationsnivå och/eller individnivå eftersom forskningen visar att det är en relativt liten andel av företagen/individer i ledande ställning som anmäls för frekvent mycket brott eller får frekvent mycket negativa myndighetsbeslut mot 
sig. Det är i runda tal endast 5-8 procent företag/individer som står för uppemot 45 procent av de totala anmälningarna/besluten per tidsenhet vilka därmed kan klassificeras som »kroniskt« kriminella (Sutherland, 1985; Clinard, 1983; Alalehto, 2010). ${ }^{12}$ När det gäller denna senare ansats krävs mer specificerade regleringsåtgärder för att stävja problemet på organisations-/individnivå, istället för åtgärder på samhällsnivå.

Denna senare bild av hur regleringsåtgärderna måste specificeras blir mest tydlig på individnivå där förövarpopulationen uppvisar samma indelning i karriärkriminella och tillfälleskriminella förövare som vid traditionell brottslighet. Detta kan man se tydligast i studier av Weisburd med flera (1991) och Piquero och Weisburd (2007) som, dessvärre är de enda, studierna på området vilka visar att drygt 70 procent av förövarna är krisreagerare, ${ }^{13}$ dvs personer som kan klassificeras som tillfälleskriminella. Drygt 25 procent är förövare som söker brottstillfällen, och drygt 5 procent är klassiska kroniker (fem lagföringar eller fler). Sociodemografiskt visar dessa delpopulationer inga speciella särdrag i förhållande till varandra. Att de till övervägande grad är män (ca 80 procent), förvånar egentligen ingen kriminolog med självaktning, men det är också i stort sett det enda gemensamma drag som råder mellan ekobrottslingar och traditionella brottslingar. När det gäller övrig demografi är skillnaderna stora, i det att ekobrottslingar överlag är medelålders, gifta/samboende, har en hygglig förmögenhet, har en regelbunden inkomst liksom en regelbunden anställning samt att de tillhör den etniska majoriteten i landet. Ekobrottslingar är kort sagt en demografisk anomali som förövarpopulation gentemot traditionella brottslingar (Alalehto och Larsson, 2011; 2012). Det betyder dock inte att förövarpopulationen av ekobrottslingar är speciellt homogen, i själva verket finns det en variation inom populationen. Den består dels av vilken ingång till ekobrottsligheten individen har, dels av vilken typ av brott individen har begått. Vi vet att det åtminstone finns tre ingångar till ekobrottsligheten som brottsfenomen. Den första ingången är specialisterna som inte gör något annat än just ekobrott, de är för det mesta tillfällesrelaterade av yttre orsaker ( $\mathrm{t}$ ex likviditetskris). Den andra ingången är de som börjar med ekobrott, men senare blandar upp sin brottslighet med traditionella typer av brott motiverade av tillfällesrelaterade faktorer eller av individuella egenskaper. Den tredje ingången är de som börjar med traditionella brott men som senare blandar upp sin brottslighet med ekobrott (Lewis, 2002). Demografiskt skiljer sig dessa delpopulationer åt utifrån vilka ingångar till brottsligheten individen har. Det gäller inte minst medelålder, där individer med den tredje ingången i stort sett är likvärdiga med den demografiska struktur som traditionella brottslingar uppvisar. 
Ur regleringssynpunkt gäller det alltså att veta vilken typ av förövare som utför brotten och vad det är för typ av åtgärder som kan inriktas mot dessa.

Den andra aspekten i fråga om specificerade regleringsåtgärder av individer gäller brottstyp. Individer som begår kartellbrottslighet visar goda demografiska värden på samtliga ingående variabler (förmögenhet, inkomstnivå, anställningshistorik, civilstånd, försörjningsplikt, etc) mot $\mathrm{t}$ ex den som begår i huvudsak bedrägeri, förskingring eller svindleri. Den senare individen visar en demografisk struktur alltifrån att den ligger i linje med befolkningssnittet överlag till en något högre nivå än traditionella brottslingar. Det intressanta är också att just valet av brottstyp speglar till ganska övervägande del en samvariation till vilken ingång individen har in i den ekonomiska brottsligheten (Alalehto och Larsson, 2011).

Utöver detta vet vi att vissa personlighetsdrag som extroverthet, föraktfullhet, hedonism, narcissim och neuroticism är återkommande predispositiva drag som är länkade till aggressivitet, impulskontroll och omnipotens hos ekobrottslingar (se t ex Blickle mfl., 2006; Holtfreter mfl., 2010). Eftersom drygt 50 procent av personlighetsdraget är ärftligt borde det vara så att vissa genetiska förutsättningar förklarar variationen mellan ekobrottslingar och lagliga företagare och troligen även variationen inom gruppen ekobrottslingar. Utöver detta vet vi att ekonomisk brottslighet i stor utsträckning sker i samverkan mellan flera individer, så kallad co-offending (Weisburd, 1991), samt att sannolikheten för ekonomisk brottslighet är signifikant påfallande om två individer av samma tillmötesgående läggning möts i en affärsuppgörelse, gentemot om bara den ena av individerna är intresserad av brottslighet (Kim och Xiao, 2008). ${ }^{14}$

Så långt kommen $\mathrm{i}$ argumentationen kan vi konstatera att ekonomisk brottslighet som straffrättslig handling utifrån de självrapporterade data som föreligger är ett utbrett massfenomen i samhället som mest troligt begås av tillfälleskriminella individer. Men samtidigt kan vi också konstatera att ekonomisk brottslighet som polisanmäld straffrättslig handling (även inkluderade civilrättslig handling) är ett marginellt fenomen i marknaden. Det är egentligen här problemet föreligger för en effektiv reglering. Det gäller att kunna identifiera och skärskåda brottstrukturen i de brottstyper som utgör föremål främst för tillfälleskriminella individer att begå brott. Gentemot att i motsvarande mån identifiera och skärskåda brottsstrukturen i de brottstyper som är vanligast förekommande hos karriärkriminella individer. Det jag vill peka på är att man inte skall anslå ett regleringsprogram eller generell policyåtgärd som alltid och ensidigt utgår från samhällsnivå. En sådan regleringsstrategi kommer med all säkerhet att missa målet eftersom den är för grov för att reglera enskilda karriärkriminella företags/individers brottsbeteende genom åtgärder som straffar hela branscher. Risken med en sådan regle- 
ringsstrategi är att den kommer att undergräva myndigheternas legitimitet, av att agera för grovt och ställa till större oreda än vad som redan föreligger; ungefär som elefantens besök i glasbutiken. Frågan måste istället fokuseras på vad för problem som föreligger och hur brottsstrukturen ser ut vid den aktuella brottstypen.

\section{Från variabler till mekanismer}

Det jag nämnt hitintills är olika bakgrundsvariabler som samvarierar eller kan tänkas samvariera mer eller mindre signifikativt gentemot varandra. Det är naturligtvis en viktig aspekt. Men av kanske större betydelse är vilka mekanismer som så att säga processar fram eller bär fram att variablerna samvarierar i större eller mindre utsträckning när det gäller den ekonomiska brottsligheten. När det gäller just mekanismer så återstår mycket att önska när det gäller forskningen kring detta. Hur som helst, om jag bara nämner några av alla hitintills identifierade mekanismer så utgör $\mathrm{t}$ ex den externa pressen mot företagsledningen en mekanism att begå oegentligheter, denna mekanism tycks samverka med vilken uppfattning som råder inom företaget/företagen om deras oegentlighet kommer att upptäckas eller inte av kontrollerande myndighet, vilket är beroende av hur påtagligt detta hot upplevs (se t ex PwC, 2009). »Signalering« utgör en tredje mekanism som visar att om den verkställande ledningen fifflar så tjänar detta som förebild för underställda tjänstemän eller arbetare att fiffla med företagets resurser (Clinard, 1983; Shover, Hochstetler och Alalehto, 2012). Vi vet därutöver att en betydande riskfaktor bakom ekonomisk brottslighet är låg likviditet (kan ibland åtföljas av låg soliditet), samt vilken typ av branschstruktur och -kultur som är rådande där företaget är verksamt. Det vill säga om det råder en tillåtande eller avvisande branschkultur gentemot brottslighet av ekonomiska skäl (Alalehto, 2000; Engdahl, 2010; Pettersson 2011; PwC, 2007; 2009). Utöver detta finns en mekanism som kan trigga företagets ledning att vidta strategiska beslut som inte alltid följer lagens intention eller gällande förordningar. Det gäller ledarskapets kvalité, dvs personer som rör sig mellan olika företag och ser sitt ledande som en personlig karriärinvestering i motsats till personer som identifierar sig med företaget ifråga. I detta fall kan en karriärinriktad ledare mer hänsynslöst orsaka att företaget begår brott för att på pappret redovisa god likviditet och därmed lugna reella och potentiella investerare, vilket samtidigt gynnar ledarens egen ställning och framtida karriär (Alalehto, 2010).

Inom individnivån finns ytterligare ett antal mekanismer som kan tänkas bära fram brottsligheten mellan $t$ ex vissa personlighetsdrag och val av yrke utifrån aggressivitet som egenskap hos individen ( $\mathrm{ex}$ en försäljare som agerar påstridigt 
via dennes extroverthet), eller etisk flexibilitet (en opportun och anpassningsrelaterad individ), resilience (en hållning av att saker och ting studsar tillbaka, eller rinner av likt vatten på en gås), eller restraint (en bundenhet till det konventionella men samtidigt en överlägsen hållning gentemot omvärlden), som ett utslag av medelklassuppfostran att ta sig rätten att definiera och bete sig på ett visst sätt givet sitt kulturella kapital, etc (Shover och Hunter, 2010; Shover, Hochstetler och Alalehto, 2012). Dessa individuella egenskaper är mekanismer som kan tänkas bära fram en neutraliserande och till och med positiv värdering av ekobrott som något eftersträvansvärt.

Om det ligger någonting i ovanstående mekanismers frambärande av den ekonomiska brottsligheten, så är det utbredningen av dessa mekanismer som man bör sikta in sig på att reglera med lämpliga policyinriktade åtgärder.

\section{6. ... och från mekanismer till förväntningar}

Hur högt ställda förväntningar kan vi då ställa på reglering av den ekonomiska brottsligheten. Kan vi rent av reglera bort all ekonomisk brottslighet? Nej det är nog lite svårt att tänka sig. Om vi bortser (åtminstone temporärt) av alla utanpåliggande externa och aggregerade variabler som kriminaliseringsprocess, resurstilldelning till rättsväsendet, kriminalpolitiska reformförändringar, etc, och enbart koncentrerar vår analys på den hanterbara organisatoriska och individuella nivån, så ställer sig fortfarande ett antal hinder i vägen för att avreglera all ekonomisk brottslighet. För det första, marginalkostnaderna för att stävja all ekonomisk brottslighet kommer att bli kollosalt höga, beroende på att likviditetskriser är ett återkommande fenomen som kommer att drabba alla företag mer eller mindre i en konkurrensutsatt kapitalistisk marknad och/eller beroende på att företagare (i likhet med andra individer) inte är perfekta (de gör misstag, de försummar, de gör felinvesteringar, etc) och de försöker därefter bara överleva. För det andra, så långt historien uppvisar finns ständigt, med en mer eller mindre jämn fördelning över skiftande politiska och ekonomiska konjunkturer, individer som uppvisar arrogans, låg impulsivitet, nonchalans, desperation, omnipotens, etc endera på grund av sjukdom och/eller annan typ av funktionsnedsättning och/eller personlighetsdrag. För det tredje, det kommer att råda en kriminalpolitisk variation över tid och rum att definiera och erkänna vissa affärshandlingar som brottsliga och inte ett olyckligt utslag av »risky business « $\mathrm{i}$ en som det tycks väl fungerande kapitalistisk marknad (Pontell, 2005). För det fjärde, i takt med globaliseringen, så kommer speciellt de större företagen att undvika regleringsåtgärder genom att helt enkelt flytta sin produktion eller distribution till andra länder. Genom detta förfarande kan man dels välja länder som är underutvecklade ifråga om 
reglering, eller tillämpar en begränsad reglering som inte hotar företagens avsättnings- och lönsamhetsinriktning. Dessa länder har t ex inte ratificerat internationella överenskommelser vilket gör dem mottagliga för t ex miljöfarligt avfall (Chirayath mfl., 2002; Gibbs mfl., 2010). Mot detta ställs förvisso olika övernationella regleringsförslag (Harding, 2004), men effekterna av dessa är inte utredda så långt jag känner till.

Hur som helst, av allt detta kan man dra två slutsatser som är viktiga i regleringssammanhang. Den första slutsatsen gäller i vilken utsträckning ett lands ansvariga (politiker, myndighetsföreträdare, marknadsföreträdare) är beredd att bekosta stävjandet av ekonomisk brottslighet? Hur stora marginalkostnader är man beredd att ta i förhållande till det utfall man förväntar sig? Utifrån de resultat som Bussmann och Werle (2006) visar, så »lönar« sig en utvidgad apparat av kontroll och upptäcktsmekanismer ( $\mathrm{t}$ ex intern eller extern revision, risk management, forensiska metoder), i det att fler brott uppdagas i de företag som innehar denna apparat. Detta i motsats till företag, vilka saknar motsvarande kontroll- eller upptäcktsmekanismer, som uppger att de inte utsatts för något ekonomiskt brott eftersom de inte upptäckt några. Men hur stor denna »lönsamhet« är kan inte Bussmann och Werle uppge. En alternativ ansats i detta sammanhang är att arbeta mer preventivt, genom att $t$ ex utforma finansiella tjänster som kräver att producenten är ansvarig för att konsumenten är fullt medveten om vad det är för tjänst denne köper, $t$ ex genom en hårdare statlig intervenering i marknaden, via ratificerade avtal mellan ett flertal länder eller hårdare sanktionsformer inom en given definierad marknad (Gibbs mfl., 2010). Eller att politiker och myndigheter är beredd att reglera när olika konjunkturer »slår till« med åtföljande likviditetskriser hos företagare. Oavsett vilken åtgärd man tar till så måste förstås kostnaderna vägas mot förtjänsterna. I ett kapitalistiskt samhälle vill man inte gärna att ett produktivt och kreativt entreprenörskap skall förväxlas med ett spekulativt och oegentligt affärsbeteende! Vilket alltid är ett problem att avgöra i förhand, i kontrast mot att göra det $\mathrm{i}$ efterhand. När det gäller den andra slutsatsen kring individers heterogenitet och skiftande förhållningssätt till det legalistiska synsättet så är detta ett ständigt återkommande problem som återfinns $\mathrm{i}$ våra samhällen, oavsett vilket ekonomiskt-politiskt system som för tillfället är närvarande. Individens egenskaper är tyvärr i liten mån någonting som är bestämd av personen i fråga, utan avhängig dels det biologiska, dels det normativt givna av vad som uppfattas som normalt beteende hos den breda allmänheten. Ett icke-normalt beteende är ett avvikande beteende och utgör i sin förlängning, om beteendet skadar annan person eller egendom, objektet $\mathrm{i}$ all typ av kriminologisk diskussion oavsett om det handlar om ekonomisk brottslighet eller traditionell brottlighet. 


\section{Noter}

1. Tage Alalehto, docent i Sociologi vid Umeå Universitet. Han har bland annat blivit publicerad i International Journal of Offender Therapy and Comparative Criminology, Critical Criminology, Criminal Justice Studies, Journal of Financial Crime

2. http://www.bolagsverket.se/om_bolagsverket/statistik/index.asp, hämtad den 6 december 2011.

3. Detta gäller anmälningar till Konsumentverket, Arbetsmiljöverket (speciellt underrättelse-, förbud- och åtalsanmälningar samt arbetsställbesök och inspektionsmeddelanden), Konkurrensverket (specifikt upphandlingsanmälningar), Allmänna Reklamationsnämnden, Finansinspektionen (speciellt klagomål mot företag, och insider+otillbörlig marknadspåverkan+obehörigt röjande av känslig företagsinformation) samt Arbetsdomstolen och Marknadsdomstolen.

4. Se t ex Gray (2006) som etnografiskt observerade ett flertal norm, förordnings- och till och med lagstiftningsmässiga brott gentemot arbetarskyddslagstiftningen som ett normalt inslag i vardagen.

5. Ekobrottsmyndighetens årsredovisning för 2010.

6. För att läsaren skall få lite perspektiv på volymerna så utgjorde antalet bokföringsbrott mellan åren 1943 till 1962 av endast 59 rättegångsfall och 101 utredningar av det Sovjetiska kommunistpartiet (Harrison, 2011). Det var framför allt under 1970-talet som organiserad brottslighet började etablera sig på allvar i Sovjet, och i takt med en tätare förbindelse till ekonomisk brottslighet, så började korruptionen breda ut sig på allvar under Perestrojkaperioden (Gilinskiy, 2006).

7. Studier visar att när en bransch växer hastigt så ökar den ekonomiska brottsligheten bland företagen, dock till en viss punkt där brottsligheten börjar avta i förhållande till tillväxten (Zahra mfl., 2005; Baucus och Near, 1991).

8. I de återkommande enkätundersökningarna som PwC utfört globalt gällande ekonomisk brottslighet alltsedan 2003 återkommer just förskingring och bokföringsbrott som de två mest frekventa brotten.

9. Det var dock ett tal som kom att stiga, fem år senare, till att nästan var tredje brott anmäldes till norsk polis (Ellingsen 2010).

10. I det norska urvalet uppgav drygt 27 procent att de begått momsbrott; motsvarande brott i Finland var drygt 28 procent, medan det var uppemot 38 procent i Danmark och hela 46 procent $\mathrm{i}$ Island som begått momsbrott.

11. Motsvarande siffror för de nordiska länderna är: Norge 1,5 procent försäkringsbedrägerier 0,5 procent mutor; Finland 3 procent försäkringsbedrägerier och 0,2 procent mutor; Danmark 6 procent försäkringsbedrägerier och 1 procent mutor; Island 7 procent försäkringsbedrägerier och 1,5 procent mutor.

12. Det intressanta i detta sammanhang är att denna storleksordning i princip gäller på samma sätt för offerskap vid ekonomisk brottslighet. Ellingsen och Sky (2005) samt Ellingsen (2010) fann t ex att drygt 2,5 procent av 2000 respektive 1800 slumpmässigt utvalda företagare stod för närmare 60 procent av totalt 5900 lagbrott som företagarna själva rapporterade att de blivit utsatta för.

13. För en ingående kvalitativ beskrivning av denna förövarkategori se Engdahl (2011). 


\section{Tage Alalehto}

14. Så långt mig veterligen finns det ingen studie på just detta område. Däremot finns åtminstone en studie (Beaver och Holtfreter, 2009) som visat på ett signifikant samband mellan hög aktivitetsnivå av MAOA (fem eller fler allelle-par), hög frekvens av avvikande vänner och hög frekvens av bedrägligt beteende.

\section{Referenser:}

Alalehto, T. (2000) »The Act of Economic Crime: The Logic of Dirty Business and Normative Restrictions in the Swedish Restaurant Industry «, Journal of Scandinavian Studies in Criminology and Crime Prevention, 1, 156-177.

Alalehto, T. (2007) "Suspected Irregularities in Stock-Exchange-Listed Companies: What Are the Effects of Negative Publicity?«. Monatsschrift für Kriminologie und Strafrechtsreform, hefte 2/3:191-206.

Alalehto, T. (2010) »The wealthy white-collar criminals: corporations as offenders«, Journal of Financial Crime, 17, 308-320.

Alalehto, T. och Larsson, D. (2008) »Vem är den ekonomiske brottslingen? En sociodemografisk profilstudie av 23 länder«. I Alalehto, T. och Larsson, D. (eds) Den ljusskygga ekonomin: organiserad och ekonomisk brottslighet, Umeå: Umeå universitet.

Alalehto, T. och Larsson, D. (2011) »Varför ekobrottsforskningen gått i stå och hur vi skall få den att expandera! - ekobrottslingens demografi, riskfaktorer och kriminella karriär«. I: Alalehto, T. och Larsson, D. (red): Vinddriven kriminalitet på en vinddriven marknad - ekonomisk och organiserad brottslighet. Recito förlag: Borås.

Alalehto, T. och Larsson, D. (2012) »Vem är den ekonomiske brottslingen? En jämförelse mellan länder och brottstyper«. Sociologisk Forskning årgång $49 \mathrm{nr}$ 1:25-44.

Ayres, I. och Braithwaite, J. (1992) Responsive Regulation: Transcending the Deregulation Debate, Oxford University Press, USA.

Baucus, M.S. och Near, J.P. (1991) »Can Illegal Corporate Behavior Be Predicted? An Event History Analysis«, The Academy of Management Journal, 34, 9-36.

Beaver, K.M. och Holtfreter, K. (2009) »Biosocial Influences on Fraudulent Behaviors«, The Journal of Genetic Psychology, 170, 101-114.

Benson, M.L. och Cullen, F.T. (1998) Combating Corporate Crime: Local Prosecutors at Work, UPNE.

Blickle, G., Schlegel, A., Fassbender, P. och Klein, U. (2006) »Some Personality Correlates of Business White-Collar Crime«, Applied Psychology, 55, 220-233.

Blumstein, A. (1986) Criminal careers and »career criminals«, National Academies.

Braithwaite, J. (1985) »White Collar Crime«, Annual Review of Sociology, 11, 1-25.

Braithwaite, J. och Makkai, T. (1991) »Testing an Expected Utility Model of Corporate Deterrence«, Law \& Society Review, 25, 7-40.

Brody, R.G. och Luo, R. (2009) »Fraud and white-collar crime: a Chinese perspective«, Cross Cultural Management: An International Journal, 16, 317-326.

Bussmann, K.-D. och Werle, M.M. (2006) »Addressing Crime in Companies«, British Journal of Criminology, 46, 1128-1144.

Chirayath, V., Eslinger, K. och De Zolt, E. (2002) »Differential Association, Multiple Normative Standards, and the Increasing Incidence of Corporate Deviance inan Era of Globalization«, Journal of Business Ethics, 41, 131-140. 
Coffee J. C 1995 Corporate Crime and Punishment: »A Non-Chicago View of the Economics of Criminal Sanctions«. I: Orland L (red): Corporate and White Collar Crime: An Anthology. Anderson Publishing Company.

Clinard, M.B. (1983) Corporate Crime, Free Press.

Croall, H. (2009) »White collar crime, consumers and victimization«, Crime, Law and Social Change, 51, 127-146.

Deng, X. och Cordilia, A. (1999) »To Get Rich Is Glorious: Rising Expectations, Declining Control, and Escalating Crime in Contemporary China«, International Journal of Offender Therapy and Comparative Criminology, 43, 211-229.

Ellingsen, D. (2010) »Færre virksomheter utsatt?«. http://www.ssb.no/samfunnsspeilet/utg/ 201003/01/ (hämtad 120914).

Ellingsen, D. och Sky, V. (2005) »Varehandel, hotell og restaurant mest utsatt«. http://www.ssb. no/ssp/utg/200503/02/ (hämtad 120914).

Engdahl, O. (2010) Bortom girigheten. Ekonomisk brottslighet i bank- och finansbranschen., Boréa.

Engdahl, O. (2011) »White Collar Crime and Informal Social Control: The Case of »Crisis Responders« in the Swedish Banking and Finance Sector«, Sociology Mind, 01, 81-89.

Fisse, B. och Braithwaite, J. (1983) The Impact of Publicity on Corporate Offenders, SUNY Press.

Fituni, L. (2000) »Economic crime in the context of transition to a market economy«. I: Economic Crime in Russia, (ed) by Alena Ledeneva och Marina Kurkchiyan. The Hague, The Netherlands: Kluwer Law International.

Gibbs, C., McGarrell, E.F., Axelrod, M., Gibbs, C., McGarrell, E.F. och Axelrod, M. (2010) »Transnational white collar crime and risk, Transnational white collar crime and risk«, Criminology \& Public Policy, Criminology \& Public Policy, 9, 9, 543, 543-560, 560.

Gilinskiy, Y. (2006) »Crime in Contemporary Russia«, European Journal of Criminology, 3, 259-292.

Grabosky, P. och Shover, N. (2010) »Forestalling the Next Epidemic of White collar Crime«, Criminology \& Public Policy, 9, 641-654.

Gray, G.C. (2006) »The Regulation of Corporate Violations«, British Journal of Criminology, $46,875-892$.

Halla, M. och Schneider, F. (nd) »Taxes and Benefits: Two Distinct Options to Cheat on the State? «, SSRN eLibrary.

Halleröd, B. och Larsson, D. (2008) »In-work Poverty in a Transitional Labour Market: Sweden, 1988-2003«. I: Andreß, H.-J. och Lohmann, H. (ed) The Working Poor in Europe. Employment, Poverty and Globalization, Cheltenham UK, Northampton, MA, USA, Edward Elgar Publishing, 155.178.

Harding, C. (2004) »Forging the European Cartel Offence: The Supranational Regulation of Business Conspiracy«, European Journal of Crime, Criminal Law and Criminal Justice, 12, 275-300.

Harrison, M. (2011) »Forging success: Soviet managers and accounting fraud, 1943-1962«, Journal of Comparative Economics, 39, 43-64. 


\section{Tage Alalehto}

Hetzler, A. (2003) »Vita lögner och blå dunster: manipulationer i finansmarknadernas gråzoner«. I: Korsell, L (red): Förebyggande metoder mot ekobrott - en antologi. BRÅ-rapport 2003:10. Stockholm.

Holtfreter, K., Beaver, K.M., Reisig, M.D. och Pratt, T.C. (2010) »Low self-control and fraud offending «, Journal of Financial Crime, 17, 295-307.

Kahan, D.M. och Posner, E.A. (1999) »Shaming White-Collar Criminals: A Proposal for Reform of the Federal Sentencing Guidelines«, Journal of Law \& Economics, 42, 365.

Kim, Y. och Xiao, N. (2008) »FraudSim: Simulating Fraud in a Public Delivery Program«. Paper.

Korsell, L.E. (2003) Bokföringsbrott: en studie i selektion, Kriminologiska institutionen, Stockholms universitet.

Larsson, D. och Halleröd, B. (2011) »Sweden: The Impact of Policy and Labour Market Transformation«. I: Fraser, N., Gutiérrez, R., och Peña-Casas, R. (eds) Working poverty in Europe. Basingstoke. Palgrave Macmillan.

Larsson, P. (2002) A straffe, veilede eller overtale? - En studie av fire tilsynsmyndigheters reguleringsstrategier. Det Kriminalitetsforebyggende Råd, KRÅD, Oslo.

Larsson, P. (2011) »Det farlige næringslivet: Reguleringen av økonomisk kriminalitet i det 21 århundre«. I: Alalehto, T. och Larsson, D. (red): Vinddriven kriminalitet på en vinddriven marknad-ekonomisk och organiserad brottslighet. Recito förlag: Borås.

Levi, M. (2002) »Suite Justice or Sweet Charity? Some Explorations of Shaming and Incapacitating Business Fraudsters «, Punishment \& Society, 4, 147-163.

Lewis, R.V. (2002) White collar crime and offenders: a 20-year longitudinal cohort study, San Jose, Writers club press.

Mann K, Wheeler S, och Sarat A. (1995) »Sentencing the White Collar Offender«. I: Orland L (ed): Corporate and White Collar Crime: An Anthology. Anderson Publishing Company.

Paternoster, R. och Simpson, S. (1996) "Sanction threats and appeals to morality: Testing a rational choice model of corporate crime «, Law \& Society Review, 30, 549-583.

Pettersson, L. (2011) »Är formell kontroll en kriminogen faktor i åkerinäringen? « I: Alalehto, T. och Larsson, D. (red): Vinddriven kriminalitet på en vinddriven marknad - ekonomisk och organiserad brottslighet. Recito förlag: Borås.

Piquero, N.L. och Weisburd, D. (2009) »Developmental Trajectories of White-Collar Crime«. I: Simpson, S. och Weisburd, D. (ed) The Criminology of White-Collar Crime. Springer. USA.

Pontell, H.N. (2005) »Control fraud, gambling for resurrection, and moral hazard: Accounting for white-collar crime in the savings and loan crisis«, Journal of Socio-Economics, 34, 756770.

Posner R.A. (1995) »Optimal Sentences for White Collar Criminals«. I: Orland L (ed): Corporate and White Collar Crime: An Anthology. Anderson Publishing Company.

Price Water House Coopers. (2007; 2009; 2011) The Global Economic Crime Survey.

Shover, N. Hochstetler, A. och Alalehto, T. (2012) »Choosing White-Collar Crime«. I: Cullen, F.T. och Wilcox, P. (ed) The Oxford Handbook of Criminological Theory. Oxford University Press, USA.

Shover, N. och Hunter, B. (2010) Blue collar, white-collar: Crimes and Mistakes. I: Bernasco, W. (ed) Offenders on Offending: Learning About Crime from Criminals. Portland: Willan. 
Simpson S. (1992) »Corporate-Crime Deterrence and Corporate-Crime Control Policies. Views from the Inside«. I: Schlegel, K. och Weisburd, D. White-Collar Crime Reconsidered. Boston. Northeastern University Press.

Simpson, S.S. och Koper, C.S. (1992) »DETERRING CORPORATE CRIME*«, Criminology, 30, 347-376.

Smith, N.C., Simpson, S.S. och Huang, C.Y. (2007) »Why managers fail to do the right thing: An empirical study of unethical and illegal conduct«, Business Ethics Quarterly, 17, 633667.

Sutherland, E.H. (1985) White Collar Crime: The Uncut Version, Yale University Press.

Walt, S. och Laufer, W.S. (1992) »Corporate Criminal Liability and the Comparative Mix of Sanctions«. Schlegel, K. och Weisburd, D. White-Collar Crime Reconsidered. Boston: Northeastern University Press.

Weisburd, D. (1991) Crimes of the middle classes: White-collar offenders in the federal courts, Yale Univ Pr.

Weisburd, David, Waring, E. och Chayet, E. (1995) "SPECIFIC DETERRENCE IN A SAMPLE OF OFFENDERS CONVICTED OF WHITE COLLAR CRIMES*«, Criminology, 33, 587-607.

Williams, C. och Renooy, P. (2008) »Measures to tackle undeclared work in the European Union. European Foundation for the Improvement of Living and Working Conditions « (Eurofound). REGIOPLAN, Netherlands.

Zahra, S.A., Priem, R.L. och Rasheed, A.A. (2005) »The Antecedents and Consequences of Top Management Fraud«, Journal of Management, 31, 803-828. 